\title{
Atlantic observation of Calanus marshallae (Copepoda; Calanoida)
}

\author{
Rolf C. Sundt*, Webjorn Melle \\ Institute of Marine Research, PO Box 1870 Nordnes, N-5024 Bergen, Norway
}

\begin{abstract}
An observation of Calanus marshallae Frost, 1974, on the Atlantic side of the Polar Ocean is reported. Copepods were identified by comparing nucleotide sequences of mitochondrial $16 \mathrm{~S}$ ribosomal RNA with a previously reported sequence from the Pacific region. Presence of the species in the Barents Sea may explain multi-modal length distributions previously obtained in the region. Potential implications for future identification of Calanus spp. in this region are discussed.
\end{abstract}

KEY WORDS: Calanus marshallae - Calanus finmarchicus - Calanus glacialis - Mitochondrial DNA 16S ribosomal RNA $\cdot$ Molecular species identification

\section{INTTRODUCTION}

Calanus spp. are considered to be the most important secondary producers in the marine food-web in Atlantic and Arctic water masses in the north-east Atlantic. The copepods have a key role as a link between primary production and many species of commercially exploited fish (e.g. Pavshtiks 1956, Hassel et al. 1991). Besides C. hyperboreus with its population center in the Greenland Sea (Conover 1988, Hirche 1991), the genus is represented by 2 other important species in the region. C. glacialis is an Arctic species with its centre of distribution over the shallow shelf surrounding the Arctic Ocean (Hirche 1991). C. finmarchicus is an Atlantic species with 2 centres of distribution, in the Subpolar Gyre south of Greenland and in the southern Norwegian Sea (e.g. Aksnes \& Blindheim 1996). C. hyperboreus, C. glacialis and C. finmarchicus have overlapping distributions at the front between Atlantic and Arctic water masses in the northeast Atlantic (Hassel 1986, Hirche et al, 1994).

During identification of copepods for a population genetic study of Calanus finmarchicus, 3 out of 7 adult females of Calanus spp. smaller than $3 \mathrm{~mm}$ were identified as C. marshallae. The sample was collected 8

\footnotetext{
•E-mail: rolf.sundt@imr.no
}

August 1994 in Arctic water in Isfjorden, Spitsbergen at 50 to $250 \mathrm{~m}$ (Fig. 1). The reported main distribution of C. marshallae is over the shelves of the north Pacific and in the Bering Sea (Frost 1974). Previous records of the species north of the Bering Strait, near Banks Island (Frost 1974), are some $2300 \mathrm{~km}$ from the present observation (Fig. 1).

\section{METHODS}

Copepods were preserved in $95 \%$ ethanol for $3 \mathrm{yr}$ before DNA was PCR (polymerase chain reaction) amplified using the primers 16SAR: 5 '-CGCCTGTTTAACAAAAACAT-3' and 16SBR: 5'-CCGGTTTGAACTCAGATCACGT-3' (Palumbi et al. 1991). Amplification products were checked for size and purity using electrophoresis in $2 \%$ Metaphore $^{\mathrm{rM}}$ gel. Product bands were cut from the gel and the DNA was extracted and purified using Sephaglas ${ }^{\mathrm{TM}}$ BandPrep Kit (Pharmasia Biotech). Templates were sequenced using the 16SBR primer. Cycle sequencing was run using fluorescently labelled di-deoxy terminators according to the manufacturer's recommended conditions (Applied Biosystems, Inc., ABI). For details see Bucklin \& Kocher (1996). Unincorporated primers and dNTPs (deoxyribonucleotide triphosphates) were removed using Autose ${ }^{\text {TM }}$ G-50 columns (Pharmacia Biotech). Nucleo- 


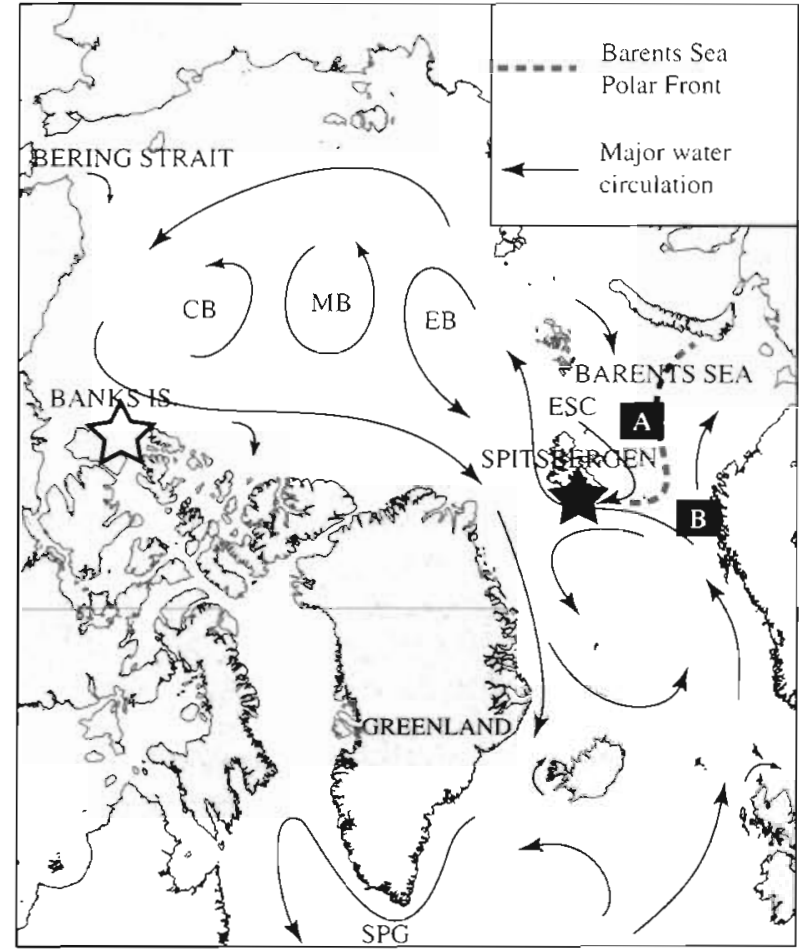

Fig. I Major circulation in the Atlantic and Arctic Oceans [after Grotefent et al. (in press); coastlines from GMT (Generic Mapping Tools), Wessel \& Smith (1995)]. ( $\star$ ) Present observation of Calanus marshallae; ( 5 ) observations from Frost (1974). CB: Canadian Basin; MB: Makarov Basin; EB: Eurasian Basin; ESC: East Spitsbergen Current; SPG: Subpolar Gyre. Rectangles A and B denote sampling areas for stations presented in Fig. 3 tide sequencing was carried out in an ABI Automated DNA Sequencer, Model 377. The sequences were further compiled using the program Sequencing Analysis 3.0 and checked thoroughly for accurate machine reading. Specimens were identified by comparing nucleotide sequences of a 387 base pair portion of the mitochondrial $16 \mathrm{~S}$ ribosomal RNA gene with a previous reported sequence of Calanus marshallae collected in Puget Sound, Washington, USA (Bucklin et al. 1995).

\section{RESULTS}

The haplotype from the present study (same for all 3 individuals) differed with one transition (one pyrimidine base has been substituted for the other) from the 387 base pair sequence of Calanus marshallae from the Pacific region (Fig. 2). The sequence difference between the closest related species $C$. marshallae and C. glacialis is $7.3 \%$, whereas it is approximately 1 to $2 \%$ within individuals of $C$. finmarchicus (Bucklin et al. 1995). The most common C. finmarchicus haplotype in the Spitsbergen sample and a C. glacialis haplotype from Gulf of St. Lawrence are given in Fig. 2.

\section{DISCUSSION}

Calanus marshallae could have been advected to Spitsbergen from the Arctic Ocean (Fig. 1), but it is also possible that the species maintains a local population and co-occurs with $C$. finmarchicus and $C$.

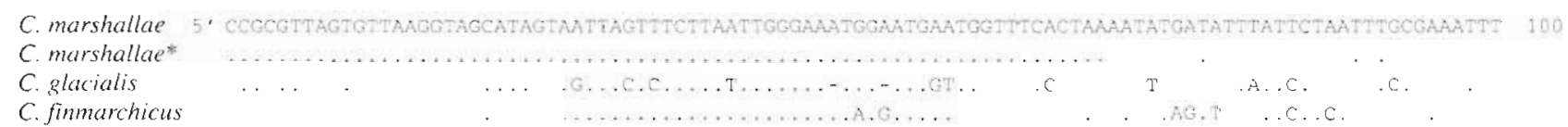

C. marshallae

C. finmarchicus . $\quad \ldots \ldots \ldots \ldots \ldots \ldots \ldots \ldots \ldots \ldots \ldots$

C. marshallae

C. marshallae*

C. glacialis

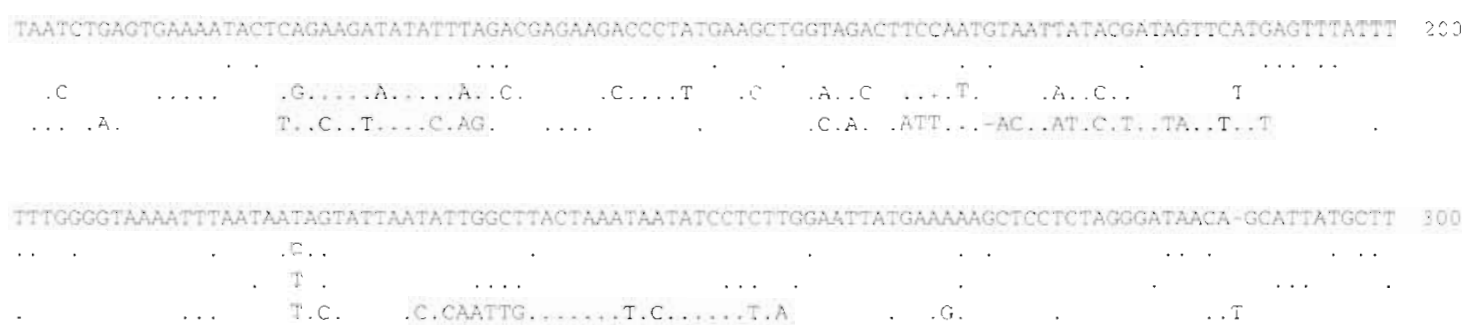

C. marshallae

C. marshallae*

C. glacialis

C. finmarchicus

C. marsizallae

C. marshallae*

C. glacialis

C. finmarchicus

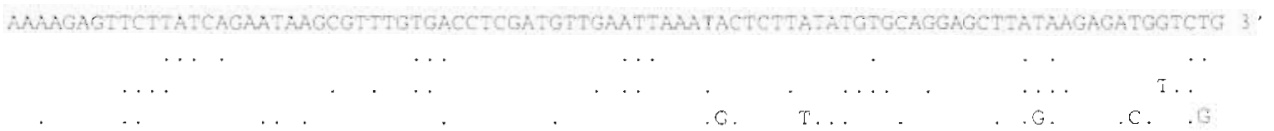

Fig. 2. Calanus spp. Sequence data for a 387 base pair region of the mitochondrial 16S rRNA gene for C. marshallae and C. finmarchicus (most common haplotype) from the Spitsbergen sample. C. marshallae* and C. glacialıs from Bucklin et al. (1995). 


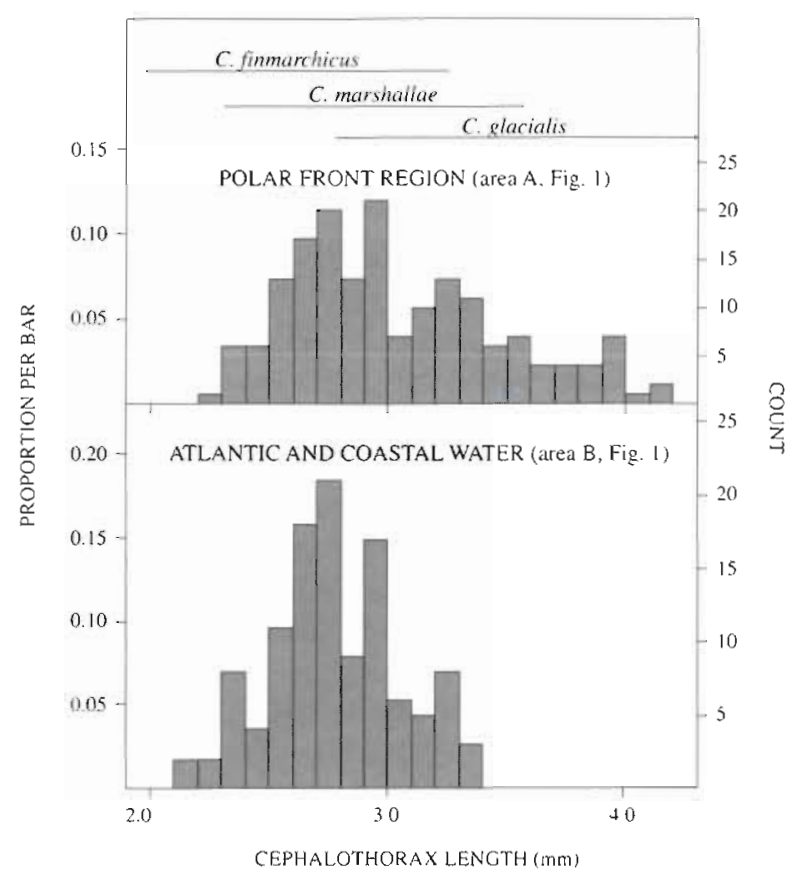

Fig. 3. Calanus spp. Example of distribution of cephalothorax length of adult females. Data obtained at 14 stations in Atlantic and Coastal water masses (lower panel) and 9 stations in the Polar front region of the Barents Sea (upper panel, see Fig. 1 for sampling areas). Range of cephalothorax lengths, including extremes, given in upper panel (Frost 1974)

glacialis in the Barents Sea region. Length measurements of the Calanus spp. stocks of cold water regions, for example the Barents Sea, have revealed that length distributions of $C$. finmarchicus and $C$. glacialis overlap to a great extent (Jaschnov 1972, Frost 1974). In length distributions of Calanus spp. obtained from the Polar front region of the Barents Sea, intermediatesized specimens are abundant (Fig. 3). In copepods it is known that individuals of a given developmental stage tend to be larger at low temperatures (Deevey 1960, Grainger 1961, McLaren 1965, Carlotti et al. 1993), and intermediate-sized specimens could be individuals of C. finmarchicus or C. glacialis brought into colder or warmer water, respectively. Intermediate-sized specimens have also been suggested to be hybrids of $C$. finmarchicus and C. glacialis (Jaschnov 1972), although this was rejected by Frost (1974) because intermediate-sized specimens are found in areas where the species exist alone as well. Thus, an intermediate-sized sibling species of $C$. finmarchicus and C. glacialis may be common in the Polar front region of the Barents Sea. The observation of $C$. marshallae in Arctic water west of Spitsbergen suggests that identification with special focus on this species should be undertaken in the Barents Sea and the north-east Atlantic as a whole.
Because of differences in length of life cycle among species (Tande et al. 1985), correct identification is important for studies of production and system ecology.

Large-scale identification based on morphological characters is laborious and to some extent uncertain. The species can also be identified based on differences in proteins (Sevigny \& McLaren 1988). However, this technique has major drawbacks like the need for continuos cryogenic preservation to avoid degradation of samples. Nucleotide sequences from PCR products separate the species unambiguously and are very sensitive with respect to the amount of sample needed, but it is too expensive for screening of large numbers of individuals. We are currently making attempts to develop methods based on RAPD (random amplified polymorphic DNA) and restriction analysis of PCR amplified DNA that eventually will allow unambiguous identification of ethanol preserved samples at lower costs.

Acknowledgements. This work is supported by funding from the European Commission, 'Trans Atlantic Study of Calanus', project PL 950016. We thank Tor Knutsen for help with the 'Generic Mapping Tools' and 3 anonymous referees for helpful comments on the manuscript.

\section{LITERATURE CITED}

Aksnes DL, Blindheim J (1996) Circulation patterns in the North Atlantic and possible impact on populations of Calanus finmarchicus. Ophelia 44:7-28

Bucklin A, Frost BW, Kocher TD (1995) Molecular systematics of six species of Calanus and three species of Metridia (Copepoda; Calanoida). Mar Biol 121:655-664

Bucklin A, Kocher TD (1996) Source regions for recruitment of Calanus finmarchicus to Georges Bank: evidence from molecular population genetic analysis of mtDNA. Deep Sea Res 43(7-8):1665-1681

Carlotti F, Krause M, Radach G (1993) Growth and development of Calanus finmarchicus related to the influence of temperature-experimental results and conceptual model. Limnol Oceanogr 38(6):1125-1134

Conover RJ (1988) Comparative life histories in the genera Calanus and Neocalanus in high latitudes of the northern hemisphere. Hydrobiologia 167/168:127-142

Deevey GB (1960) Relative effects of temperature and food on seasonal variations in length of marine copepods in some eastern American and western European waters. Bull Bingham Oceanogr Collect Yale Univ 17:54-85

Frost BW (1974) Calanus marshallae, a new species of calanoid copepod closely allied to the sibling species $C$. finmarchicus and C. glacialis. Mar Biol 25:77-99

Grainger EH (1961) The copepods Calanus glacialis and C. finmarchicus (Gunnerus) in Canadian Arctic-Subarctic waters. J Fish Res Bd Can 28:663-678

Grotefent K, Logemann K, Quadfasel D, Ronski S (in press) Is the Arctic Ocean warming? J Geophys Res

Hassel A (1986) Seasonal changes in zooplankton composition in the Barents Sea, with special attention to Calanus spp. (Copepoda). J Plankton Res 2:329-339 
Hassel A, Skjoldal HR, Gjøsæeter H, Loeng H, Omli L. (1991) Impact of grazing from capelin (Mallotus villosus) on zooplankton: a case study in the northern Barents Sea in August 1985. In: Sakshaug E, Hopkins CCE, Øritsland NA (eds) Proc Pro Mare Symp Polar Mar Ecol, Trondheim, 12-16 May 1990. Polar Res 10(2):371-388

Hirche HJ (1991) Distribution of dominant copepod species in the Greenland Sea during fall. Polar Biol 11:351-362

Hirche HJ, Hagen W, Mumm N, Richter C (1994) The Northeast Water Polynya, Greenland Sea. 3. Mesozooplankton and macrozooplankton distribution and production of dominant herbivorous copepods during spring. Polar Biol $14(7): 491-503$

Jaschnov WA (1972) On the systematic status of Calanus glacialis, C. finmarchicus and C. helgolandicus. Crustaceana 22(3):279-284

McLaren IA (1965) Some relationships between temperature and egg size, body size, developmental rate, and fecundity, of

Editorial responsibility: Otto Kinne (Editor),

Oldendorf/Luhe, Germany the copepod Pseudocalanus. Limnol Oceanogr 10:528-538 Palumbi SR, Martin A, Romano S, McMillan WO, Stice L, Garbowski G (1991) The simple fool's guide to PCR, Ver 2 . Department of Zoology, University of Hawaii, Honululu

Pavshtiks EA (1956) Seasonal changes in plankton and feeding migrations of herring. Trudy PINRO 99:3-123

Sevigny JM, McLaren IA (1.988) Protein polymorphism in six species of the genus Calanus. Hydrobiologia 167/168: $275-284$

Tande KS, Hassel A, Slagstad D (1985) Gonad maturation and possible life cycle strategies in Calanus finmarchicus and Calanus glacialis in the northwestern part of the Barents Sea. In: Gray JS, Christensen ME (eds) Marine biology of polar regions and effect of stress on marine organisms. Proc 18th Eur Mar Biol Symp, Oslo, 14-20 August 1983 John Wiley \& Sons Ltd, Chichester, p 141-155

Wessel P, Smith WHF (1995) New version of the Generic Mapping Tools released. EOS Trans Am Geophys Union 76:1- 329

Submitted: January 27, 1998; Accepted: March 31, 1998 Proofs received from author(s): April 24, 1998 